U.D.C. 662.66 .094 .3

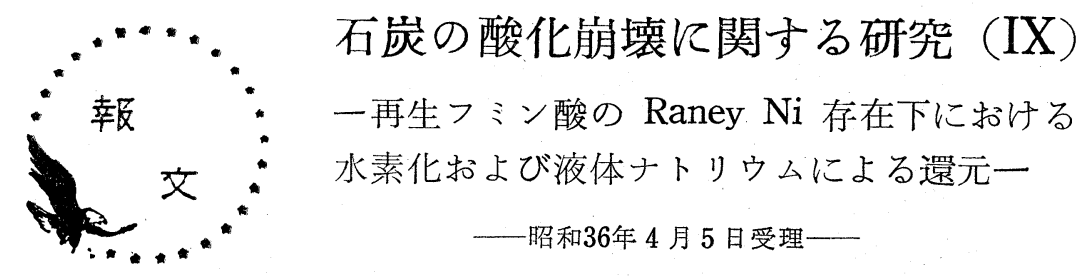

京都大学工学部 梶山 茂・横川親雄・武上善信

要旨: 一大ノ浦歴青炭を $1 \mathrm{~N} \mathrm{HNO}_{3}$ の沸点で5hrs 酸化して得たフミン酸について, (1) Raney $\mathrm{Ni}$ 存在下での水素化反応，(2) 液体アンモニア・ナトリウムを用いる還元反応を行なった。

(1)での生成物について化学分析, 赤外線吸収スペクトルの測定を行ない, 反応温度 $170^{\circ} \mathrm{C}$ 以 下では官能基に括いて水素化反応が起こり， $250^{\circ} \mathrm{C}$ 以上では人造石炭化過程に類似の反応が起 こることを認めた。

また反応過程の検討から，さきに示した大ノ浦フミ酸の示性式はほぼ妥当なものであると考 えられた。

(2)では反応生成物の $\mathrm{OH}$ 基の増量を測定することによって大ノ浦フミン酸には分子量604に つき 0.9 原子のエーテル型酸素が含まれていることを示した。

\section{I. 緒論}

著者らは現在まで行なつてきた研究1) 5りにおいて，

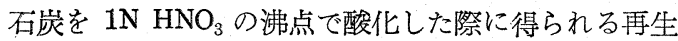
フミン酸が石炭の化学構造研究においてきわめて重要 な試料であることに注目して，その構造について詳し く検討した。

本報においてはさきに報告したフミン酸の示性式 を再検討する意味で，再生フミン酸について Raney
$\mathrm{Ni}$ の存在下で階段的水素化ならびに液体アンモニア ・ナトリウムによる還元を行なつた。

II. Raney Ni の存在下における水素化反応

1)メチル化フミン酸およびフミン酸の水素化反応 まずメチル化フミン酸, ついでフミン酸の水素化を 行ない, 緩徐な条件下でのフミン酸の水素化過程につ いて検討した。

メチル化フミン酸としては大ノ浦歴青炭を $1 \mathrm{~N} \mathrm{HNO}_{3}$

第 1 表 メチル化フミン酸および再生フミン酸の Raney Ni 存在下における水素化反応の結果

\begin{tabular}{|c|c|c|c|c|c|c|c|c|c|c|c|c|c|c|c|}
\hline \multirow{2}{*}{$\begin{array}{l}\text { 実験 } \\
\text { 番号 }\end{array}$} & \multicolumn{2}{|r|}{ 反 応 } & \multicolumn{2}{|c|}{ 条 件 ${ }^{1)}$} & \multirow{2}{*}{$\begin{array}{c}\mathrm{CH}_{4} \\
\%\end{array}$} & \multicolumn{5}{|c|}{ 媒体可溶分分析值(\%)(d.a.f.) } & \multicolumn{5}{|c|}{ 媒体不溶分分析值(\%)(d.a.f.) } \\
\hline & 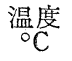 & $\begin{array}{l}\text { 平力 } \\
\text { atm }\end{array}$ & $\begin{array}{l}\text { 時間 } \\
\mathrm{hr}\end{array}$ & $\begin{array}{l}\text { 触媒量 } \\
\text { gr }\end{array}$ & & 収量 & C & $\mathrm{H}$ & $\mathrm{OCH}_{3}$ & 扊分 ${ }^{2)}$ & C & $\mathrm{H}$ & $\mathrm{N}$ & $\mathrm{OCH}_{3}$ & 灰分 ${ }^{2)}$ \\
\hline 1 & 100 & $2 \sim 3$ & 5 & 0.5 & - & 7.8 & 67.0 & 6.1 & 12.4 & 4.8 & 68.2 & 4.7 & 3.0 & 8. 2 & 0.4 \\
\hline $\begin{array}{l}2 \\
3\end{array}$ & 120 & $\begin{array}{r}95 \\
110\end{array}$ & "I & "I & - & $\left.\begin{array}{l}5.8 \\
8.1\end{array}\right\}$ & 66.9 & 6.1 & - & 0.9 & $\begin{array}{l}68.5 \\
68.8\end{array}$ & $\begin{array}{l}5.0 \\
5.0\end{array}$ & $\begin{array}{l}3.0 \\
3.1\end{array}$ & $\begin{array}{l}8.3 \\
8.0\end{array}$ & $\begin{array}{l}\mathrm{Ni1} \\
0.6\end{array}$ \\
\hline $\begin{array}{l}4 \\
5 \\
6\end{array}$ & $\begin{array}{l}150 \\
\text { "I } \\
170\end{array}$ & $\begin{array}{l}145 \\
125 \\
160\end{array}$ & $\begin{array}{r}11 \\
10 \\
5\end{array}$ & $\begin{array}{l}11 \\
11\end{array}$ & $\begin{array}{l}3.7 \\
3.5 \\
4.0\end{array}$ & $\left.\begin{array}{l}2.4 \\
6.0 \\
2.5\end{array}\right\}$ & 72.4 & 8.3 & - & 2.4 & $\begin{array}{l}70.8 \\
70.7 \\
70.6\end{array}$ & $\begin{array}{l}5.1 \\
5.2 \\
5.0\end{array}$ & $\begin{array}{l}3.1 \\
3.0 \\
2.9\end{array}$ & $\begin{array}{l}8.2 \\
8.1 \\
7.8\end{array}$ & $\begin{array}{l}3.6 \\
6.1 \\
3.4\end{array}$ \\
\hline $\begin{array}{l}7 \\
8\end{array}$ & $\begin{array}{l}180 \\
170\end{array}$ & $\begin{array}{l}150 \\
\prime \prime\end{array}$ & 12 & $\begin{array}{l}1.0 \\
\text { I/ }\end{array}$ & $\begin{array}{l}4.5 \\
5.0\end{array}$ & $\left.\begin{array}{l}2.4 \\
2.0\end{array}\right\}$ & 71.0 & 8.2 & - & 2.6 & $\begin{array}{l}71.5 \\
73.7\end{array}$ & $\begin{array}{l}5.1 \\
5.0\end{array}$ & $\begin{array}{l}3.2 \\
2.9\end{array}$ & $\begin{array}{l}7.1 \\
3.6\end{array}$ & $\begin{array}{l}3.7 \\
3.9\end{array}$ \\
\hline 9 & 160 & 110 & 5 & 11 & - & 4. 5 & 65.7 & 8.7 & - & 2.1 & 68.3 & 5.7 & - & - & 8.4 \\
\hline 10 & "I & "I & 12 & $" 1$ & - & 7. 2 & 66.1 & 8. 6 & - & 2.7 & 68.6 & 5.3 & - & - & 4.7 \\
\hline & & & & & & & & & & & & & & 口和当量 & \\
\hline 11 & 120 & 110 & 5 & 0.5 & - & 3.5 & 65.9 & 6.5 & - & 2.6 & 65.7 & 4.5 & 3.0 & 196 & 0.4 \\
\hline 12 & 160 & 155 & "I & "I & 4.0 & 2.5 & 69.9 & 8.1 & - & 4.5 & 69.7 & 5.0 & 2.9 & 244 & 4. 3 \\
\hline
\end{tabular}

\footnotetext{
1）媒体：メタノール，圧力：反応温度における圧力 実験 $9 ， 10$ は触媒としを W-4 Raney Ni 他は W-7 Raney Ni を用いた。 実験 1〜10 はメチル化フミン酸, 実験 11,12 はフミン酸を試料とした。

2) 無水基準
} 
で $5 \mathrm{hrs}$ 酸化して得た再生フミン酸のメチル化物 $\left(\mathrm{Hm}<\mathrm{COOCH}_{3}\right)$ を試料とした。このものの分析值はつ ぎのようである。

O $65.9 \%, \mathrm{H} 4.5 \%, \mathrm{OCH}_{3} 12.9 \%$ ，扊分 $3.0 \%$

Raney Ni としてはケトン, フェノールなぞの水素 化に有効であるという理由で W-7 Raney $\mathrm{Ni}^{6}$ )を用 い，また媒体としてメタノールを用いて反応温度 180 ${ }^{\circ} \mathrm{C}$ 以下で反応させた。水素化反応条件ならびにそれ それの生成物の分析値を第 1 表に示した。

生成物の一部はメタノール（媒体）に可溶であるが, その量はきわめて少なく，大部分は不溶である。

$120^{\circ} \mathrm{C}$ 以下では水素化反応沛るるかであるが, $\mathrm{C} \%, \mathrm{H} \%$ もやや増大し, 反応温度を $150^{\circ} \mathrm{C}$ 上げ

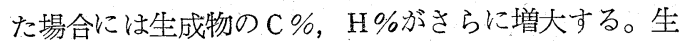
成物の $\mathrm{OCH}_{3} \%$ は $120 \sim 170^{\circ} \mathrm{C}$ の反応温度において 大体同程度であり，このことから比較的水素化をうけ 易い $\mathrm{COOCH}_{3}$ 基が存在することがわかる。また $150^{\circ} \mathrm{C}$ 以上では $\mathrm{CH}_{4}$ の生成が認められることから $\mathrm{COOCH}_{3}$ 基の水素化によつて生成した $\left(\mathrm{CH}_{2} \mathrm{OH}\right)$ がさらに脱七 ドロキシメチル化2ををうけてメタンを生じたと考えら れる。

$170^{\circ} \mathrm{C}$ で $12 \mathrm{hrs}$ 水素化すれば, $\mathrm{CH}_{4}$ 生成量の増加 と $\mathrm{OCH}_{3}$ 基の急激な減少がみられ，これは残つている $\mathrm{COOCH}_{3}$ 基についても上と同種の反応が起こるものと 解釈されうる。

つぎに第 1 表の実験 9,10 に-4 Raney Ni を 用いて水素化した場合の結果を示した。この結果から，
W-4 Raney Ni を用いたときの水素化過程は生成物 の分析值ならびに $\mathrm{CH}_{4}$ 生成量からみて, W-7 Raney $\mathrm{Ni}$ を用いた場合よりも反応が幾らか緩徐であるが， 反応の性格は $\mathrm{W}-7$ Raney $\mathrm{Ni}$ の場合と同じである といえる。

第 1 表実験 $11 ， 12$ はメチル化フミン酸と比較する 意味でフミン酸 (C. $65.4 \%, \mathrm{H} \mathrm{4.0 \% ,} \mathrm{N} \mathrm{3.4 \% ,} \mathrm{中}$ 和当量 190,210$)$ をメ夕ノール媒体で反応温度 $120^{\circ} \mathrm{C}$ および $160^{\circ} \mathrm{C}$ で水素化したものである。

$120^{\circ} \mathrm{C}$ の場合, 生成物の元素組成は原料フミン酸の それとほとんど変らないが, 中和当量の值はアルカリ 側から酸側へ滴定した場合とその逆の場合と同じ值を 示している。原料フミン酸ではこの二つの值が異なり この原因は解離し難い酸性基に基くものと考えたが， フミン酸を水素化したときには，このような部分が水 素化をうけて解離し易い構造の酸性基に変化したもの と思われる。

反応温度 $160^{\circ} \mathrm{C}$ では生成物の中和当量の值が大きく なつており，一部脱崖酸したことを示している。

2 ) フミン酸のカリウム塩の Raney $\mathrm{Ni}$ 存在下に 打汀る水素化反応

前項においては反応温度 $180^{\circ} \mathrm{C}$ 以下で水素化反応 を行なつたのであるが， $200^{\circ} \mathrm{C}$ 以上で反応させるため 次のような実験を行なつた。

媒体として水を用い，試料としては水可溶の状態で 反応させるためフミン酸のカリウム塩を用いた。この 条件での水素化反応結果を第 2 表に示した。

\section{第 2 表 大ノ浦フミン酸のカリウム塩の Raney Ni 存在下における水素化反応結果}

\begin{tabular}{|c|c|c|c|c|c|c|c|c|c|c|c|c|c|c|}
\hline \multirow[b]{2}{*}{ 番号 } & \multicolumn{3}{|c|}{ 反応条件1) } & \multicolumn{6}{|c|}{ アルカリ可溶分分析值 (d.a.f.) } & \multicolumn{5}{|c|}{ アルカリ不溶分分析值 (d.a.f.) } \\
\hline & $\begin{array}{l}\text { 温度 } \\
{ }^{\circ} \mathrm{C}\end{array}$ & . 压力 & $\begin{array}{c}\text { 触媒量 } \\
\text { gr }\end{array}$ & $\begin{array}{c}\text { 収量 } \\
\%\end{array}$ & $\mathrm{C} \%$ & $\mathrm{H} \%$ & $\mathrm{~N} \%$ & 中和当量 & $\begin{array}{r}\text { 灰分 } 2 \text { \% }\end{array}$ & 収量％ & $\mathrm{C} \%$ & $\mathrm{H} \%$ & $\mathrm{~N} \%$ & $\begin{array}{r}\text { 灰分 }{ }^{2)} \\
\%\end{array}$ \\
\hline 13 & 200 & 200 & 0.5 & 69 & $74 \cdot 2$ & 5.3 & 2.0 & 225 & 1.7 & - & - & - & - & - \\
\hline & 250 & 265 & "I & 27 & 75.1 & 5.6 & 1.5 & 220 & 0.7 & 36 & 80.1 & 6.1 & 1.8 & 3.6 \\
\hline & 300 & 260 & 1. 0 & 19 & 77.9 & 6.8 & 1.3 & 193 & 5.4 & 34 & 82.3 & 7.3 & nil & 26.9 \\
\hline & 320 & 300 & $\mathbb{1}$ & 20 & 82.1 & 7.1 & nil & 225 & 4.4 & 18 & 82.7 & 7.5 & nil & 21.9 \\
\hline
\end{tabular}

（註）反応ガス中に $\mathrm{CH}_{4}$ は認められなかった。

1) 媒体：水，反応時間： $5 \mathrm{hrs}$. ただし実験 16 のみ $12 \mathrm{hrs}$, 圧力：反応温度飞括行る圧力

2）無水基準

大ノ浦フミン酸のカリウム塩を水媒体で反応温度 $200 \sim 300^{\circ} \mathrm{C}$ において水素化した場合（実験13１6） には反応温度とともに $\mathrm{C} \%$, H\%が増大する。この温 度範囲での反応は複雑な反応を含んでいるであろうと 思われるが， $300^{\circ} \mathrm{C}$ まで反応させた場合にも $\mathrm{CH}_{4}$ の 生成が認められず，著しい分解反応は起こつていない
と考えられる。

$200^{\circ} \mathrm{C}$ における生成物は水に溶解しており，酸によ つて大部分が沈澱してくる。このものの中和当量は原 フミン酸に比較的近い值であるが, $\mathrm{C} \%, \mathrm{H} \%$ は相当大 きくなつている。この部分を酸不溶分と呼ふことにす

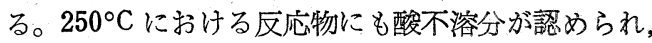


このものの組成は $200^{\circ} \mathrm{C} て ゙ の$ 生成物と大差はない。 またこの場合にはアルカリ不溶分 $(3,000$ r.p.m. で $20 \mathrm{~min}$ 遠心分離したとき沈澱するもの) 功相当量生成 し,このものはアルカリに不溶であるから酸性基を含 有していないと思われる。300ㄷ では酸不溶分および アルカリ不溶分の収量はともに減少し，いずれの $\mathrm{C} \%$ ， H\%，もさらに増大している。これらの生成物の収量 の減少は, 水素化分解によつて一部が分解し, 酸によ つて沈澱しない低分子量の酸可溶分が生成したためと みられる。 $320^{\circ} \mathrm{C} て ゙ ~ 12 \mathrm{hrs}$ 水素化した場合はさらに この傾向分顕著にあらわれるが，生成物の元素組成は C 82\%, H 7\%前後にほほ一致してくる。

3 ）水素化生成物の赤外線吸收スペクトル,

水素化反応過程を論じるための一助として, 水素化 生成物の赤外線吸収スペクトルを測定した。

メチル化フミン酸の 水素化生成物では, 反応温度 $120^{\circ} \mathrm{C}$ での生成物 (実験 3 ) そ $150^{\circ} \mathrm{C}$ での生成物（実

第 1 図
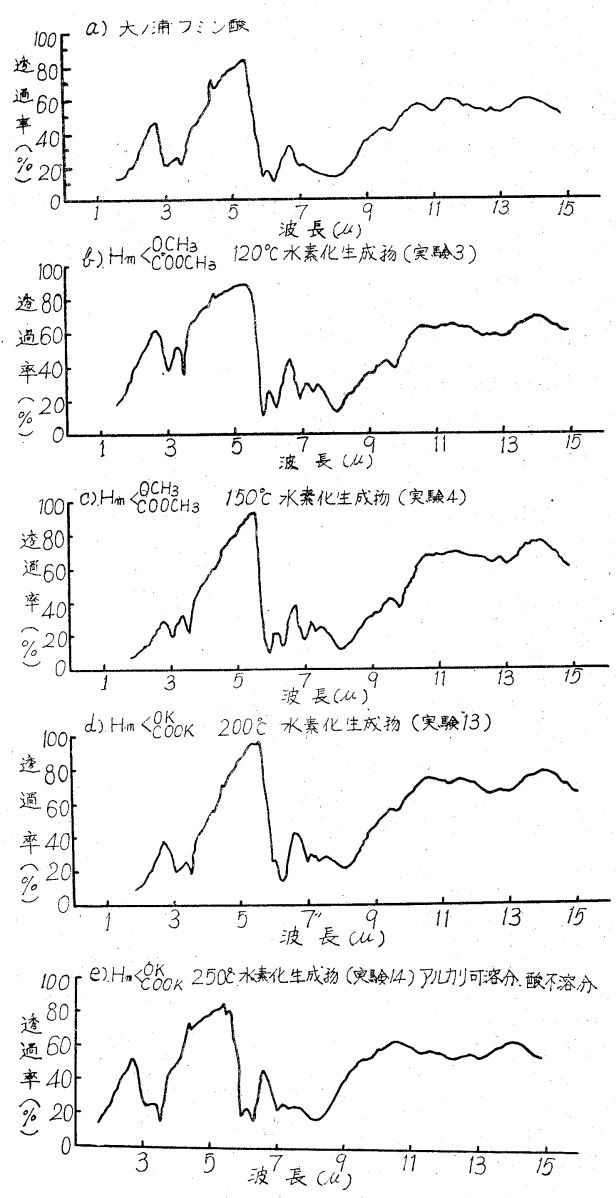

第， 図
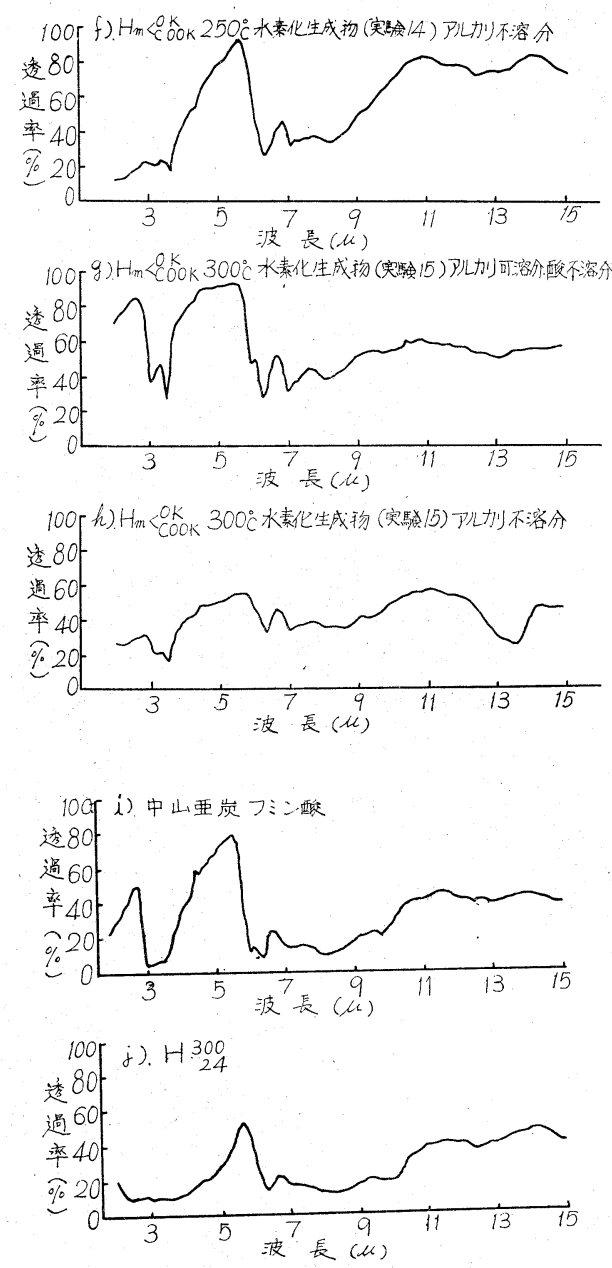

験 4 ) との間に元素組成の差違（C\%で約 $2 \%)$ が認 められたので, この両者を比較したが, 赤外線吸収ス ペクトルの結果では両者の間には特記すべき相違は認 められなかつた。これらは大ノ浦フミン酸のスペクト ルと比べると, $3.5 \mu$ 附近の脂肪族 $\mathrm{CH}$ 吸収や $7 \mu$ 附 近の $\mathrm{CH}_{2}$ または $\mathrm{CH}_{3}$ の吸收が増加している。また $150^{\circ} \mathrm{C}$ での水素化生成物においてもカーポニル基 $(5.8$ $\sim 5.9 \mu$ ）の吸収が認められる。

フミン酸カリウム塩の $200^{\circ} \mathrm{C}$ 水素化生成物（実験 13）の赤外線吸収スペクトルは，明らかに>CO の吸 収 $(5.8 \sim 5.9 \mu)$ が不明膫となり, カーボニル基, カ ルボキシル基が減少したことを示している。 $250^{\circ} \mathrm{C}$ 水 素化生成物の酸不溶分の赤外吸収スペクトルでは, 水 素添加反応が進んだことを示す $3.5 \mu$ の吸収が明膫と なり，わずかながら>CO の吸收も認められるが,ア 
ルカリ不溶分の赤外線吸収スペクトルでは $>\mathrm{CO}$ の吸 収は完全に消失している。 $300^{\circ} \mathrm{C}$ 水素化生成物の酸不 溶分では $250^{\circ} \mathrm{C}$ 水素化生成物の酸不溶分における 同傾向のスペクトルを示し，アルカリ不溶分では幾分 低波長における背景の吸收が大きくなつているが，大 体 $250^{\circ} \mathrm{C}$ の場合と同じ傾向のスペクトルを与えてい る。

これらの試料はいずれも単一物質ではなく集合体で

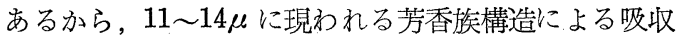
は平均化されるおそれがあるが，吸収スペクトルの結 果方ら推定すると, 高温度における水素化生成物の芳 香族核の縮合度も原フミン酸のそれと大差はないもの と思われる。

\section{III. 液体アンモニア・ナトリウム還元}

前報2において再生フミン酸中のエーテル型酸素を 定量する目的でヨウ化水素酸還元を行ない，このもの には分子量 604 につき 1.2 原子のエーテル型酸素が存 在するという結果を得た。

しかし，この定量法は再生フミン酸から一連の反応 が定量的に起こつたという仮定を前提としたもので, 定量法としては多少疑問点のあつたことは否定できな い。ここでは再生フミン酸について直接エーテル型酸 素を定量する目的で, 液体アンモニア・ナトリウムに よる還元を行なつた。この還元法については詳しい綜 報7も発表されているが，エーテル型酸素の切断反応 は極めて円滑に進みその際 $\mathrm{OH}$ 基夯生成する（R-O$\left.\mathrm{R}^{\prime} \rightarrow \mathrm{R}-\mathrm{OH}+\mathrm{R}^{\prime} \mathrm{H}\right)$ 。 したがつて増加した $\mathrm{OH}$ 基の定

第3表 大ノ浦フミン酸のナトリウム（カリウム） 液体アンモニア還元結果

\begin{tabular}{|c|c|c|c|c|c|c|}
\hline \multirow[b]{2}{*}{ 番号 } & \multicolumn{2}{|c|}{ 反応条件 } & \multicolumn{4}{|c|}{ 生成物分析值(\%)(d.a.f.) } \\
\hline & $\begin{array}{l}\text { 反応 } \\
\text { 温度 } \\
{ }^{\circ} \mathrm{C}\end{array}$ & $\begin{array}{c}\text { 反底 } \\
\text { 時間 } \\
\mathrm{hr}\end{array}$ & C & $\mathrm{H}$ & $\begin{array}{l}\mathrm{OH} \\
\text { 增量1) }\end{array}$ & 灰分 $^{22}$ \\
\hline $\mathrm{Na}$ & -50 & 2 & 68.5 & 5.8 & - & 0.1 \\
\hline "I & " & 6 & 68.5 & 5.0 & 2.8 & 1.2 \\
\hline "I & "I & 9 & 68.3 & 5.0 & 2.4 & 1.9 \\
\hline "I & -33 & 3 & 68.6 & 5.8 & - & 1.1 \\
\hline $\mathrm{K}$ & -50 & 8 & 68.4 & 5.2 & - & 0.8 \\
\hline
\end{tabular}

1) (生成物 $\mathrm{OH} \%)$ - (試料フミン酸 $\mathrm{OH} \%)$ $\mathrm{OH}$ はアセチル化法により測定

2）無水基準

量によつてエーテル型酸素を定量することができる。

第 3 表に反応条件ならびに生成物の分析值を示した。 実験 $17 \sim 19$ は反応温度 $-50^{\circ} \mathrm{C}$ で反応時間の影響を みたものであり, 実験 20 は反応温度一 $33^{\circ} \mathrm{C}$ 場合, ま た実験21はナトリウムよりも還元力が强いといわれる
カリウムを用いた場合の結果である。これらの反応条 件の如何にかかわらず，生成物の組成は一定しており， したがつていずれの場合にも反応が円滑に進み所期の 反応が終了しているものと判断された。

\section{IV. 考察}

再生フミン酸について上述のような還宇反応を行な つたのであるが，この結果を用いてさきに提出した再 生フミン酸の示性式2をを再検討しょう。

$$
\begin{aligned}
\mathrm{C}_{29.6} \mathrm{H}_{20.3} \mathrm{O}_{0.7} \mathrm{~N}_{0.5} \mathrm{~S}_{0.1}(-\mathrm{O}-)_{1.2} \\
\\
(\mathrm{COOH})_{3}(\mathrm{OH})_{0.7}(\mathrm{CO})_{0.4}(\mathrm{NO})_{1}
\end{aligned}
$$

まず Raney Ni の存在下でメチル化フミン酸を階 段的に水素化した場合について述べる。

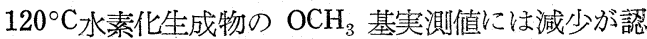
められるから，上の示性式においてメチル化フミン酸 の $\mathrm{COOCH}_{3}$ 基の中の約 1 個が $\mathrm{CH}_{2} \mathrm{OH}$ 汇変換されたこ とにあたる。いま1. 2 個の $\mathrm{COOCH}_{3}$ 基が， $\left(\mathrm{COOCH}_{3}\right)_{1.2}$ $\longrightarrow\left(\mathrm{CH}_{2} \mathrm{OH}\right)_{1.2}$ となり, また $\mathrm{NO}$ 基がアミンに還元さ れた $\left[(\mathrm{NO})_{1} \rightarrow\left(\mathrm{NH}_{2}\right)_{1}\right]$ として反応生成物の元素組成 および $\mathrm{OCH}_{3}$ 基含量を計算すると，C $68.7 \% ， \mathrm{H} 5.2$ $\%\left(\mathrm{OCH}_{3} 7.8 \%\right)$ となり, 実測值の $\mathrm{C} \%, \mathrm{H} \%$ とよく 一致する。赤外線吸收スペクトルがメチル化フミン酸 $の 120^{\circ} \mathrm{C}$ での水素化物と原料フミン酸とではほとんぞ 違わないことを考慮すると, $120^{\circ} \mathrm{C}$ での水素化では $\mathrm{COOCH}_{3}$ の $\mathrm{CH}_{2} \mathrm{OH}$ への 反応が主であつて, 他の部 分に注余り変化注效かつたといえる。

$150 \sim 170^{\circ} \mathrm{C}$ での水素化反応でも上と同様に約 1 個 の $\mathrm{COOCH}_{3}$ 基の減少があるら，この場合には前段階で 生じた $\left(\mathrm{CH}_{2} \mathrm{OH}\right)_{1.2}$ が $(\mathrm{H})_{1.2}$ になつた（脱七ドロキ シメチルによるメタンの生成はこの条件で起こる）と して計算すると，水素化生成物は C $70.3 \% ， \mathrm{H} 5.2 \%$ $\left(\mathrm{OCH}_{3} 8.2 \%\right)$ と計算される。これらの元素分析值も 実測值とよく一致するからこの際の主反応は $\mathrm{COOCH}_{3}$ の還元により生成した $\mathrm{CH}_{2} \mathrm{OH}$ の脱七ドロ キシメチル化反応であるといえる。

つぎにフミン酸の水素化について述べると，生成物

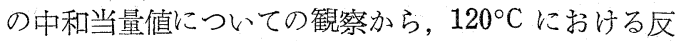
応澥離し難い酸性基の水素化反応であると考えられ， 水素化によつて解離し易くなるような酸性基*がフミ ン酸中に存在することを示唆している。

*たと光ばラクトンなどの構造型式が考光られる。<smiles>C=C(C)C1=C(C)COC([14CH2]C(C)=C(C)CCC)C1</smiles> 
$160^{\circ} \mathrm{C}$ での水素化では(夷験 12$)(\mathrm{COOH})_{1} \longrightarrow$ $\left(\mathrm{CH}_{2} \mathrm{OH}\right)_{1} \longrightarrow(\mathrm{H})_{1}$ (もしくは值接脱炭酸)および NO $\longrightarrow \mathrm{NH}_{2}$ の反応が起こつたとすると, 反応生成物の元 素組成ならびに中和当量は，C $70.4 \%, H 4.8 \%$, eq wt 248 と詮算され，実測值とよく一致する。

つぎにフミン酸のカリウム塩の水素化について述べ る。 $200^{\circ} \mathrm{C}$ 水熬化生成物では, 赤外線吸收スペクトル の結果から，原フミン酸よりは $\mathrm{OH}$ 基が増加し, >CO 基が減少していることが認められた。このものの中和 当量は, $\mathrm{COOH}$ 基が減少しているにもかかわらず 220 程度であるから，この水素化段階であらたに酸性基が 生成するものと思市れる。この酸性基は多分芳香族工 ーテル酸素の開裂によるフェノール性 $\mathrm{OH}$ であろうと 考えられる。

$250^{\circ} \mathrm{C}$ 水素化生成物の酸不溶分は元素組成, 中和当 量および赤外線吸收スペクトルの結果からみると, $200^{\circ} \mathrm{C}$ 水素化生成物に比べ $\mathrm{C} \%, \mathrm{H} \%$ 乙幾分高くな り, 赤外線吸収スペクトルでは, $\mathrm{OH}, \mathrm{CH}$ の吸収 $(3 \mu$, $3.2 \mu, 3.5 \mu)$ がより明瞭になることから, 幾分水素 化が進んだものと思われるが，全体的にみるとほ注同 一の性格をもつものと考えられる。アルカリ不溶分で は赤外線吸収スペクトルの結果ならびにこのものがア ルカリに不溶であることから, 酸性基は存在せず, こ のものが重縮合生成物であるかあるい酸性基を含む 構造部分 (フェノール構造) が崩壊して生成したもの であろうと推論される。一方天然フミン酸およびその 人造石炭の赤外線吸収スペクトルの結果と比較すれば, $3 \mu$ 附近の吸収バンドの状況に類似がみられることか ら, 人造石炭化過程に近い前者の場合の反応が起こつ ている可能性が多いと考えられる。

$300^{\circ} \mathrm{C}$ 以上では, $250^{\circ} \mathrm{C} に$ に予いてみられるような 人造石炭化類似の反応が進んでいるものと解釈される。

以上各温度段階における水素化反応を示性式を基に して考察したが, 特徵的な生成物の変化 $\left(\mathrm{OCH}_{3}\right.$ 基や 中和当量の増減など) に注目して，また各温度範囲で 当然起こるであろうと考えられる反応を仮定して計算 した值と実測值に満足すべき一致をみたことは，この 示性式がほほ妥当であるごとを示すものである。

最後に液体アンモニア・ナトリウム還元の結果につ いて述べる。こ反応によつて生成した $\mathrm{OH}$ 基は $2.6 \%$ (平均)であり, 他の官能基の還元は起らず，エーテル 酸素の切断による以外新らしい $\mathrm{OH}$ 基の生成はないか ら,エーテル型酸素は再生フミン酸分子量 604 につき $(-\mathrm{O}-)_{0.9}$ と計算される。

ヨウ化水素酸還元によつて求めた值 $(-\mathrm{O}-)_{1.2}$ は多
くの反応を経由して求められたものであり，実験の性 質を考慮に入れると, 両者の一致泗足すべきもので あるといえる。したがつて再生フミン酸は分子量 604 につき0.9〜1.2原子のエーテル型酸素をもつていると 結論される。

以上を要約すると.

1 ) 再生フミン酸およびそのメチル化物の水素化反 応 $\left(170^{\circ} \mathrm{C}\right.$ 以下) では, 基本構造に大きな変化はなく, 反応は主として官能基において起こり，また再生フミ ン酸のカルボシル基の中約 1 個は他のカルボキシル基 よりも水素化反応をうけやすいと考えられた。

2) フミン酸のカリウム塩を水媒体で水素化した場 合には, $250^{\circ} \mathrm{C}$ 以上では人造石炭化過程類似の反庆が 起こつている。

3 ）再生フミン酸の液体アンモニア・ナトリウム還 元の結果ではフミン酸中に存在するエーテル型酸素は 0.9 原子である。

4) 求素化過程の考察によつて, さきに示したフミ ン酸の示性式はほほ妥当なものであると結論された。

V. 実

i) Raney $\mathrm{Ni}$ の存在下における水素化反応

前報1記載の方法で調製した大ノ浦フミン酸, メテ ル化フミン酸およびフミン酸のカリウム塩 $2 \mathrm{gr}$ を内容 60cc のオートクレーブ中に媒体 (メタ)ールまたは 水) $20 \mathrm{cc}$ および触媒(Raney $\mathrm{Ni} \mathrm{W}-7$ まうはW-46) $0.5 \sim 1 g r$ ととも装入し，第 1 表ならびに第 2 表に 示した条件で水素化した。

ガス状生成物はオルザットの装置を用いて分析した。 固状生成物は媒体を洰別した後, 希塩酸で Niを除去 (ジメチルグリオキシムで $\mathrm{Ni}$ の存在しないことを確 認)して後 $\mathrm{C}$ ’のなくなるまで水洗した。媒体可溶分 は, メタノール媒体の場合には湯煎上で蒸発させてメ タノールを除去, 水媒体の場合には希塩酸で酸性とし て沈澱させ, 遠心分離して酸不溶分を得た。

これらの元素分析, 中和当量および官能基の定量法 は前報2におけると全く同様である。

ii）液体アンモニア・ナトリウム還元

$\mathrm{CaCl}_{2}$ 管を附属した反応容器中で，大ノ浦フミン酸 $1 \mathrm{gr}$ (真空乾燥装置で十分乾燥したもの) に液体アン モニア約 60cc，さらにナトリウム（またはカリウム） $0.6 \mathrm{gr}$ を加え, 激しく攪伴しながら反応させた。一 $-50^{\circ} \mathrm{C}$ の場合はドライアイス・アセトン浴を用い, $-33^{\circ} \mathrm{C}$ 場合 (液体アンモニアの沸点) はドライアイス・アセ トンで泠却した還流泠却器を用いて反応させた。

反応終了後, 一夜室温に放置してアンモニアを蒸発 
させた後, 少量の水で残留するナトリウムを徐々に分 解, 分解終了後さらに水を加えて内容物を洗い出し, 希塩酸で酸性とし, 沈澱物を遠心分離した。生成物の 分析法は前報1と同様である。

iii）赤外線吸収スペクトル

測定条件は応研式 201 型ダブルビーム赤外分光光度 計を用い, $\mathrm{KBr}$ 法で $\mathrm{KBr}$ に対し試料濃度は $1 \%$, $\mathrm{KBr}$ は $500 \mathrm{mg}$ を用いた。

（附記）赤外線吸収スペクトルの測定は金沢大学工 学部工業化学教室須賀操平氏に依頼した。御好意に対

し深く謝意を表する。

文献

1) 梶山，横川，渡部，武上, 燃協誌, 37, 582 (1958)

2) 暒山，横川，渡部，武上, ibid., 38, 86 (1959).

3) 横川, 渡部, 梶山, 武上, ibid., 39, 590 (1960).

4) 横川, 梶山, 渡部, 武上, ibid., 40, 620 (1961).

5) 武上, 梶山, 横川, ibid., 40, 702 (1961).

6) 漆原他, 実験化学講座, 17 [有機化合物の反応, I (下) Jp. 309, 丸善, 昭31年.

7) G.W. Watt: Chem. Rev. 46, 317 (1950).

\section{Studies on the Oxidative Degradation of Coal (IX)}

- Catalytic Hydrogenation of Humic Acid in the Presence of Raney Ni, and Reduction of Humic Acid with Solution of Sodium in Liquid Ammonia-

by Shigeru Kajiyama, Chikao Yokokawa and Yoshinobu Takegami.

(Faculty of Engineering, Kyoto University)

SYNOPSIS:- The humic acid, which was obtained from Onoura bituminous coal wo

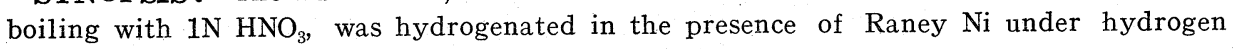
pressure.

The results of chemical analysis and infra-red spectrum of the products indicate that the functional groups of humic acid are hydrogenated at the reaction temperature below $170^{\circ} \mathrm{C}$, but, above $250^{\circ} \mathrm{C}$, the chemical change is rather analogous to the artificial coalification process. Considering the hydrogenation process, it is concluded that the rational formula of Onoura humic acid, which was reported previously, is legitimate.

The results of reduction humic acid with solution of sodium in liquid ammonia lead to the conclusion that the Onoura humic acid contains 0.9 atom of etheroxygen per molecular weight 604 . 